\title{
Flood-mediated use of habitat by large and midsized mammals in the Brazilian Pantanal
}

\author{
Patrick Ricardo De Lázari ${ }^{1,4}$, Manoel dos Santos-Filho ${ }^{1}$, \\ Gustavo Rodrigues Canale ${ }^{2}$ \& Maurício Eduardo Graipel $^{3}$
}

${ }^{1}$ Laboratório de Mastozoologia, Programa de Pós-graduação em Ciências Ambientais - PPGCA, Universidade do Estado de Mato Grosso - UNEMAT, CEP 78200-000, Cáceres, MT, Brazil

${ }^{2}$ Departamento de Ciências Biológicas, Universidade do Estado de Mato Grosso - UNEMAT, CEP 78300-000,Tangará da Serra, MT, Brazil

${ }^{3}$ Departamento de Ecologia e Zoologia, Centro de Ciências Biológicas, Universidade Federal de Santa

Catarina - UFSC, Trindade, CEP 88040-900, Florianópolis, SC, Brazil

${ }^{4}$ Corresponding author: Patrick Ricardo De Lázari, e-mail: lrpatrick@gmail.com

DE LÁZARI, P.R., SANTOS-FILHO, M., CANALE, G.R. \& GAIPEL, M.E. Flood-mediated use of habitat by large and midsized mammals in the Brazilian Pantanal. Biota Neotrop. 13(2): http://www.biotaneotropica. org.br/v13n2/en/abstract?article+bn02713022013

\begin{abstract}
The Brazilian Pantanal comprises a mosaic of forest and field environments harbouring a rich community of large and midsized mammals that are adapted to the annual hydrological cycle. Here we evaluated richness and composition of large and midsized mammals inhabiting forested and open habitats affected by yearly floods in the Pantanal in Cáceres from October 2009 to September 2010. We compared these communities in marshes, dry forests and riparian forests based on 640 camera-traps.nights, sights, tracks, faecal samples and interviews. We also compared results in a private land (Descalvados Farm) and in a protected area (Taiamã Ecological Station). In total, we sampled 26 large and midsized mammals, including five threatened and two near threatened species. Jaguars, collared peccaries and red-brocket deers were the only mammals recorded at all habitat types, while eleven species were recorded exclusively in one of the habitats. We identified a heterogeneous use of the habitat by the animal community surveyed in all three habitats during the wet and dry season. Furthermore, precipitation and river level affected the use of dry forests and marshes isolated from dry forests. Finally, 62\% of large/midsized mammal species present in the surveyed region recorded outside the reserve; therefore, we recommend conservation actions to protect those species and also to preserve unprotected dry forests.
\end{abstract}

Keywords: species richness, composition, floods, conservation, use of space.

DE LÁZARI, P.R., SANTOS-FILHO, M., CANALE, G.R. \& GAIPEL, M.E. Uso do habitat por mamíferos de médio e grande porte influenciado por inundações no Pantanal brasileiro. Biota Neotrop. (13)2: http:// www.biotaneotropica.org.br/v13n2/pt/abstract?article+bn02713022013

Resumo: O Pantanal brasileiro é formado por um mosaico de ambientes florestados e campestres, abrigando uma rica comunidade de mamíferos de médio e grande porte adaptados ao ciclo hidrológico anual. Nós avaliamos a riqueza e composição de mamíferos de médio e grande porte em habitats florestados e campestres afetados pelas inundações anuais no Pantanal de Cáceres ente outubro/2009 e setembro/2010. Comparamos as comunidades em Campos Inundáveis, Matas Secas e Matas Ripárias com base em 640 armadilhas-fotográficas.noite, avistamentos, pegadas, amostras fecais e entrevistas. Nós também comparamos os resultados em uma área privada (Fazenda Descalvados) e em uma área protegida (Estação Ecológica Taiamã). No total, foram registradas 26 espécies de mamíferos de médio e grande porte, incluindo cinco espécies ameaçadas de extinção e duas quase ameaçadas. Onças-pintadas, catetos e veados-mateiro foram os únicos mamíferos registrados em todos os habitats, enquanto que 11 espécies foram registradas em apenas um tipo de hábitat. Identificamos diferença quanto ao uso dos habitats entre os três tipos de habitats durante a estação seca e chuvosa. Além disso, a precipitação e o nível do rio afetaram o uso da Mata Seca e Campos Inundáveis isolados das Matas Secas. Por fim, $62 \%$ das espécies foram registradas fora da reserva, por isso, recomendamos ações de conservação para proteger as espécies e também para preservar as florestas secas desprotegidas.

Palavras-chaves: riqueza de espécies, composição, inundações, conservação, uso do espaço. 


\section{Introduction}

The Brazilian Wetlands (Pantanal) is known worldwide for its extraordinary wildlife, especially regarding mammals, where 174 species are recorded (Alho et al. 2011). The Pantanal plays an important role in the biological diversity maintenance, as it comprises a diverse complex of natural habitats offering opportunities for several animal species to forage, feed and reproduce (Alho 2008). Nevertheless, the Pantanal is highly under-sampled and even basic information such as species occurrence and distribution, area of occupancy and use of space by large and midsized mammals are fairly unknown (Rodrigues et al. 2002).

The Pantanals' landscape comprises a mosaic of fields and prairies surrounded by forested areas seasonally flooded (Nunes da Cunha \& Junk 2009, Alho et al. 2011). Its annual hydrological cycle leads to severe changes in this landscape, causing seasonal contraction of habitats due to floods covering a large land extension. Some mammals are better adapted than others to explore flooded and/or dry land (Mamede \& Alho 2006, Alho 2008), in addition forested habitats are generally laid at higher elevations and are used as a refuge during flood peaks (Desbiez et al. 2010). Consequently, habitats are differently used by distinct species, and species abundance and/ or population distribution are influenced by these environmental variations (Desbiez et al. 2009, Alho \& Sabino 2011, Alho \& Silva 2012).

Density of large and midsized mammals are known to increase in marshes during the dry season (Alho 2008), but only qualitative information were collected so far and little is known about the use of other environments. Understanding the variation in the use of space by large and midsized mammals in this mosaic of vegetation types is fundamental to the comprehension of the effects of flood seasonality over the community structure (Phillips et al. 2004).

Here we aimed to evaluate the richness and composition of large and midsized mammals in one protected and one private area comparing three distinct vegetations in the Pantanal. Also, we highlight the importance of understanding use of space by this community and applications to management and conservation of the species.

\section{Material and methods}

\section{Study area}

This study was conducted at the watershed of Paraguay River basin at the municipality of Cáceres, state of Mato Grosso, in two areas: a private land, Descalvados Farm (16 $43^{\prime} \mathrm{S}$ and $\left.57^{\circ} 44^{\prime} \mathrm{W}\right)$, and a protected area, Taiamã Ecological Station (reserve) $\left(16^{\circ} 50^{\prime} \mathrm{S}\right.$ and $57^{\circ} 35^{\prime} \mathrm{W}$ ) (Figure 1).

The most common vegetation at the study region is cerrado, followed by prairies and marshes, dry forests and riparian forests are also present (Silva et al. 2000). Climate is characterised by two seasons (wet and dry) with average annual temperature of $25{ }^{\circ} \mathrm{C}$ (Calheiros \& Fonseca Júnior 1996). During the wet season (October - March), average precipitation is between 1200 to 1300 mm (Cadavid Garcia 1984, Mamede \& Alho 2006), and at the study area it may vary from 700 to $1600 \mathrm{~mm}$ year-round (Neves 2006).

\section{Habitat types}

In the Pantanal, forests and fields (prairies and marshes) are affected by annual floods. The study area is located on a flat region yearly affected by floods, called Alluvial Floodplain (Pinto 1986). Subtle differences in the topographic gradient of these two areas are reflected in distinct river level (Silva 2010), area flooded and flood duration (Agência... 2004), generating a complex landscape with a diverse land cover (Nunes da Cunha \& Junk 2009). The reserve is mainly covered by marshes and riparian forests, while the private land is covered by both and also by dry forests. Here we sampled these three vegetation types.

Dry forests are deciduous forest with variable levels of leaf-drop during the dry season; it lays on dry grounds in interfluvial areas with nutrient-rich soils (Ribeiro \& Walter 1998). Riparian forests are always associated to river borders fairly common in the floodplains,

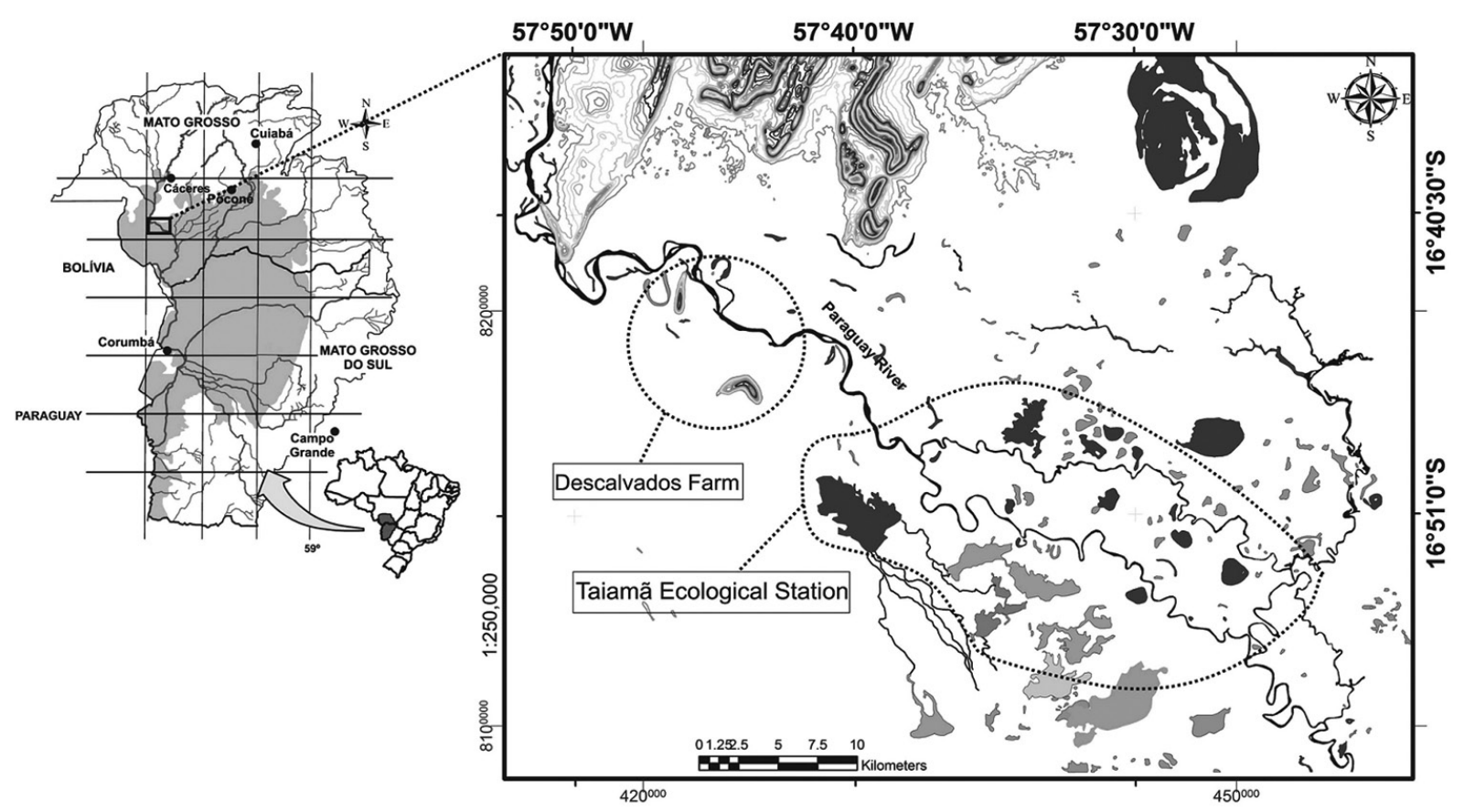

Figure 1. Map with the location of the study areas :Descalvados Farm (private land) and Taiamã Ecological Station (reserve), located both sides of the river Paraguay municipality of Cáceres, MatoGrosso state - Pantanal. Data were collected from October 2009 to September 2010. 
totally flooded during the wet season (Instituto... 1992). Finally, marshes are open lands generally present between forested lands, with high abundance of grass and Cyperaceae, totally flooded during the wet season (Silva et al. 2000).

\section{Data collection}

Confirmation of the presence of large and midsized mammals was based on sights of animals, tracks and faecal samples, five interviews with local residents and camera-trap records (Triginus $6.0 \mathrm{D})$. The association of several surveying methods allows us to improve detectability of elusive species and also species with different ranging patterns (Voss \& Emmons 1996, Santos 2003, Trolle 2003).

We evenly surveyed study sites from October 2009 to September 2010, comprising dry and wet season, and summing 80 surveyingdays. Animal sightings, tracks and faecal samples were recorded while walking on trails and dirty roads, also while installing/monitoring camera-traps or moving from one vegetation type two another by boat. Semi-structured interviews were conducted with local residents using colour plates of local fauna. Ecologically-similar African mammals, known not to occur in the region, were also shown to identify type II errors (Canale et al. 2012). Eight camera-traps were installed in each vegetation type at $40 \mathrm{~cm}$ from the ground, turned on $24 \mathrm{~h} /$ day for 10 days, and monitored for battery changes, baits (dog-food, salt and maize) replacement and animal photos every three days. Animal trails and places with abundant tracks and faecal samples were selected for camera installing; in total, we surveyed seven sites of riparian forest, six sites of dry forest and eight sites of marshes. River level was recorded every month from a specific ruler placed at both study areas by the Brazilian Navy, precipitation data was collected by the National Institute of Meteorology (INMET).

\section{Data analysis}

We used non-parametric statistics, as variables did not fit to a normal distribution, to compare species richness among the three vegetation types (Kruskal-Wallis one-way analysis of variance), and also to compare species richness between seasons (Wilcoxon rank-sum test). Spearman's correlations were conducted to verify the relation between species richness and precipitation and river level. We used a distance-based approach to verify similarity in species composition between study areas, using a NMDS based on a Jaccard similarity matrix. An analysis of similarity (ANOSIM) was carried out to evaluate the difference in species composition between the private land and reserve. Analyses were conducted using R-statistics (R Development... 2008). Species recorded exclusively by interviews and/or in aquatic environment were not considered in statistical analysis.

\section{Results}

Based on all sampling methods (including interviews), we recorded 26 large and midsized mammal species, in seven orders and 15 families (following Wilson \& Reeder 2005) in our study areas, (Table 1) $(\mathrm{N}=26$ species by interviews, 11 species by camera trap, 3 species by faecal samples, 10 species by tracks, 13 species by sightings). Seven species are considered threatened of extinction (following International... 2012), representing 26\% of large and midsized mammals recorded for our study areas. Two threatened species, lowland tapir (Tapirus terrestris) and Southern three-banded armadillo (Tolypeutes matacus), were recorded outside the reserve, but not inside it. Furthermore, only $38 \%(\mathrm{~N}=10 \mathrm{spp})$ of large/ midsized mammals were recorded inside the reserve.

For statistical analysis we considered 640 camera-trap. nights, sights, tracks and faeces records; summing 20 large and midsized mammal species recorded. Pteronura brasiliensis, Lontra longicaudis, Coendou prehensilis, Tamandua tetradactyla, Sapajus cay and Aotus azarae were recorded exclusively by interviews and/ or in aquatic environment; their arboreal/aquatic habits precluded pictorial records, thus we could not determine the use of habitats (marsh, dry forest and riparian forest) by these species and they were not considered in statistical analysis. There was no difference of species richness between seasons $(W=31, \mathrm{p}=0.1210)$. Precipitation $(\mathrm{mm} / \mathrm{month})$ and river level $(\mathrm{m})$ were positively correlated to species richness in the dry forests (precipitation: $r h o=0.83, \mathrm{p}=0.04$; river level: $r h o=0.77, \mathrm{p}=0.04)$; both were also negatively correlated to species richness in marshes (precipitation: $r h o=-1, \mathrm{p}>0.001$; river level: $r h o=-1, p>0.001)$. Species richness in the riparian forests was correlated to neither. Richness of large/midsized mammals was higher at the private land than at the reserve $(W=91.5, \mathrm{p}=0.007)$, reaching nineteen and four species for each area, respectively (Table 1) (interviews excluded).

Jaguar (Panthera onca), red brocket deer (Mazama americana) and collared peccary (Pecari tajacu) were the only species recorded at all three habitat types. Six species were located only in dry forests (T. matacus, C. paca, P. cancrivorus, N. nasua, T. pecari, M. gouazoubira), also four species were exclusively observed in riparian forests (E. barbara) and marshes (D. novemcintus, $E$. sexcinctus, $C$. thous) when they were adjacent to dry forests in the private land. In addition, the giant anteater (M. tridactyla) was observed only in riparian forests inside the reserve (Table 1).

In general, species richness was not different among vegetation types (Kruskal-Wallis $X^{2}=5.37, \mathrm{df}=2, \mathrm{p}=0.07$ ), considering the private land and reserve together (Figure 2). Comparing each vegetation type separately for each study area (private land and reserve), however, species richness in the dry forests $(\mathrm{N}=13$ species) was higher than in the marshes $(\mathrm{N}=10$ species $)(W=40.5, \mathrm{p}=0.02)$. Furthermore, dry forests in the private land $(\mathrm{N}=13$ species) were richer than the marshes inside the reserve $(\mathrm{N}=2$ species) $(W=33$, $\mathrm{p}=0.009)$, but not different from marshes in the private land $(\mathrm{N}=8$ species $)(W=7.5, \mathrm{p}=0.73)$. No other significant relation was observed when comparing species richness among distinct vegetation types $(\mathrm{p}>0.05)$.

In addition, we observed that large and midsized mammals' composition within each sampled area (reserve $v s$ private land) is different (ANOSIM $\mathrm{r}=0.48, \mathrm{p}=0.001,999$ permutations), but sites within the reserve presented more similarity among then when compared with sites outside the reserve (Figure 3).

\section{Discussion}

Large and midsized mammals' richness observed in the study region $(\mathrm{N}=26 \mathrm{spp}$.) was similar to other studies (Schaller 1983-31 species, Alho et al. 1987 - 20 species, Trolle 2003 - 27 species, Mamede \& Alho, 2006 - 30 species), and species richness different between private land and reserve is due to hydrological factors. The reserve is predominantly covered by marshes and riparian forest patches along the Paraguay River, being almost completely flooded during the rain season. The lowland at this region is enclosed by an enlarged bifurcation of the river and during flood peaks the water cover the marshes and the understory of riparian forests leaving no dry ground for terrestrial mammals (Silva et al. 2007). Floods at the private land, however, reach a smaller area and lower level, leaving unflooded florest available (Agência... 2004).

Eleven out of 20 species recorded there showed some level of restriction regarding the use of space, being detected only in one of the three sampled habitats; this is likely related to specific ecological needs for each of the large and midsized mammals of the Pantanal. In 
Table 1. List of large and midsized mammals in Pantanal at Cáceres, Mato Grosso, Brazil, recorded at three distinct habitat types. Historical records refer to presence of animals before 1974 massive flood reported in interviews. Threaten category according to Brazilian Redlist (Brasil 2008) and IUCN (International... 2012).

\begin{tabular}{|c|c|c|c|c|c|c|c|c|}
\hline Species & $\begin{array}{c}\text { Common } \\
\text { name }\end{array}$ & $\begin{array}{c}\text { Record } \\
\text { type }\end{array}$ & Marsh & $\begin{array}{c}\text { Dry } \\
\text { Forest }\end{array}$ & $\begin{array}{c}\text { Riparian } \\
\text { Forest }\end{array}$ & Interview & $\begin{array}{l}\text { Historical } \\
\text { records }\end{array}$ & $\begin{array}{l}\text { Threaten } \\
\text { category }\end{array}$ \\
\hline \multicolumn{9}{|l|}{ Artiodactyla Cervidae } \\
\hline Mazama americana & Red Brocket Deer & $\mathrm{C}, \mathrm{I}, \mathrm{S}, \mathrm{Tc}$ & $\mathrm{P}^{\mathrm{w}}$ & $\mathrm{P}^{\mathrm{wd}}$ & $\mathrm{P}^{\mathrm{w}}$ & $\mathrm{P}$ & & - \\
\hline Mazama gouazoubira & Brown Brocket Deer & $\mathrm{S}, \mathrm{I}$ & & $\mathrm{P}^{\mathrm{d}}$ & & $\mathrm{P}$ & & - \\
\hline Blastocerus dichotomus & Marsh Deer & $\mathrm{C}, \mathrm{S}, \mathrm{I}$ & $\mathrm{P}^{\mathrm{d}}$ & $\mathrm{P}^{\mathrm{d}}$ & & $\mathrm{P}, \mathrm{R}$ & & $\mathrm{Vu}$ \\
\hline \multicolumn{9}{|l|}{ Tayassuidae } \\
\hline Pecari tajacu & Collared Peccary & $\mathrm{C}, \mathrm{I}, \mathrm{S}, \mathrm{Tc}$ & $\mathrm{P}^{\mathrm{w}}$ & $\mathrm{P}^{\mathrm{wd}}$ & $\mathrm{P}^{\mathrm{w}}$ & $\mathrm{P}$ & $\mathrm{R}$ & - \\
\hline Tayassu pecari & White-lipped Peccary & C, I, S & & $\mathrm{P}^{\mathrm{w}}$ & & $\mathrm{P}, \mathrm{R}$ & & $\mathrm{Nt}^{*}$ \\
\hline \multicolumn{9}{|l|}{ Carnivora } \\
\hline \multicolumn{9}{|l|}{ Canidae } \\
\hline Cerdocyon thous & Crab-eating Fox & $\mathrm{I}, \mathrm{Tc}$ & $\mathrm{P}^{\mathrm{w}}$ & & & $\mathrm{P}$ & $\mathrm{R}$ & - \\
\hline \multicolumn{9}{|l|}{ Felidae } \\
\hline Leopardus pardalis & Ocelot & $\mathrm{C}, \mathrm{I}, \mathrm{Tc}$ & $\mathrm{P}^{\mathrm{w}}$ & $\mathrm{P}^{\mathrm{wd}}$ & & $\mathrm{P}$ & & - \\
\hline Panthera onca & Jaguar & $\mathrm{C}, \mathrm{F}, \mathrm{I}, \mathrm{S}, \mathrm{Tc}$ & $\mathrm{P}^{\mathrm{d}}, \mathrm{R}^{\mathrm{d}}$ & $\mathrm{P}^{\mathrm{wd}}$ & $\mathrm{P}^{\mathrm{w}}, \mathrm{R}^{\mathrm{wd}}$ & $\mathrm{P}$ & & $\mathrm{Vu}$ \\
\hline Mustelidae & & & & & & $\mathrm{P}$ & & \\
\hline Eira barbara & Tayra & $\mathrm{C}, \mathrm{I}$ & & & $\mathrm{P}^{\mathrm{w}}$ & $\mathrm{P}$ & & - \\
\hline Pteronura brasiliensis & Giant Otter & $\mathrm{I}, \mathrm{S}^{\mathrm{r}}$ & & & & $\mathrm{P}, \mathrm{R}$ & & $\mathrm{Vu}$ \\
\hline Lontra longicaudis & Neotropical Otter & I & & & & $\mathrm{P}, \mathrm{R}$ & & \\
\hline \multicolumn{9}{|l|}{ Procyonidae } \\
\hline Nasua nasua & South American Coati & $\mathrm{I}, \mathrm{S}$ & & $\mathrm{P}^{\mathrm{d}}$ & & $P$ & $\mathrm{R}$ & - \\
\hline Procyon cancrivorus & Crab-eating Raccoon & $\mathrm{C}, \mathrm{I}, \mathrm{S}$ & & $\mathrm{P}^{\mathrm{wd}}$ & & $\mathrm{P}$ & $\mathrm{R}$ & - \\
\hline \multicolumn{9}{|l|}{ Perissodactyla } \\
\hline \multicolumn{9}{|l|}{ Tapiridae } \\
\hline Tapirus terrestres & Brazilian Tapir & $\mathrm{F}, \mathrm{I}, \mathrm{Tc}$ & & $\mathrm{P}^{\mathrm{wd}}$ & $\mathrm{P}^{\mathrm{w}}$ & $\mathrm{P}$ & & $\mathrm{Vu}^{*}$ \\
\hline \multicolumn{9}{|l|}{ Rodentia } \\
\hline \multicolumn{9}{|l|}{ Erethizontidae } \\
\hline Coendou prehensilis & Brazilian Porcupine & I & & & & $\mathrm{P}$ & & - \\
\hline \multicolumn{9}{|l|}{ Dasyproctidae } \\
\hline Dasyprocta azarae & Azara's Agouti & $\mathrm{C}, \mathrm{I}, \mathrm{S}, \mathrm{Tc}, \mathrm{Tp}$ & & $\mathrm{P}^{\mathrm{wd}}$ & $\mathrm{P}^{\mathrm{w}}$ & $\mathrm{P}, \mathrm{R}$ & & - \\
\hline \multicolumn{9}{|c|}{ Caviidae } \\
\hline Hydrochoeris hydrochaeris & Capybara & $\mathrm{C}, \mathrm{F}, \mathrm{I}, \mathrm{S}, \mathrm{Tc}$ & $\mathrm{R}^{\mathrm{wd}}$ & & $\mathrm{P}^{\mathrm{d}}, \mathrm{R}^{\mathrm{d}}$ & $\mathrm{P}, \mathrm{R}$ & & - \\
\hline \multicolumn{9}{|c|}{ Cuniculidae } \\
\hline Cuniculus paca & Paca & $\mathrm{I}, \mathrm{Tc}$ & & $\mathrm{P}^{\mathrm{w}}$ & & $\mathrm{P}$ & & - \\
\hline \multicolumn{9}{|l|}{ Cingulata } \\
\hline \multicolumn{9}{|l|}{ Dasypodidae } \\
\hline Euphractus sexcinctus & Six-banded Armadillo & $\mathrm{I}, \mathrm{S}$ & $\mathrm{P}^{\mathrm{w}}$ & & & $\mathrm{P}$ & & - \\
\hline Tolypeutes matacus & $\begin{array}{l}\text { Southern Three-banded } \\
\text { Armadillo }\end{array}$ & $\mathrm{I}, \mathrm{Tp}$ & & $\mathrm{P}^{\mathrm{w}}$ & & $\mathrm{P}$ & & $\mathrm{Nt}^{*}$ \\
\hline Dasypus novemcinctus & Nine-banded Armadillo & $\mathrm{I}, \mathrm{Tc}$ & $\mathrm{P}^{\mathrm{w}}$ & & & $\mathrm{P}$ & $\mathrm{R}$ & - \\
\hline \multicolumn{9}{|l|}{ Pilosa } \\
\hline \multicolumn{9}{|l|}{ Myrmecophagidae } \\
\hline Myrmecophaga tridactyla & Giant Anteater & $\mathrm{C}, \mathrm{I}$ & & & $\mathrm{R}^{\mathrm{w}}$ & $\mathrm{P}, \mathrm{R}$ & & $\mathrm{Vu}$ \\
\hline Tamandua tetradactyla & Southern Tamandua & I & & & & $\mathrm{P}$ & & \\
\hline \multicolumn{9}{|l|}{ Primata } \\
\hline \multicolumn{9}{|l|}{ Atelidae } \\
\hline Alouatta caraya & Black Howler Monkey & $\mathrm{I}, \mathrm{S}$ & & & $\mathrm{P}^{\mathrm{w}}, \mathrm{R}^{\mathrm{wd}}$ & $\mathrm{P}, \mathrm{R}$ & & - \\
\hline \multicolumn{9}{|l|}{ Cebidae } \\
\hline Sapajus cay & $\begin{array}{l}\text { Hooded capuchin } \\
\text { monkey }\end{array}$ & I & & & & $\mathrm{P}, \mathrm{R}$ & & - \\
\hline Aotus azarae & Azara's night monkey & I & & & & $\mathrm{P}$ & & - \\
\hline
\end{tabular}

Tc - track; C - camera-trap; F - faecal samples; I - interview; S - sighting; Tp - Trap; Vu - vulnerable; Nt - near threatened; P - Private land; R - Reserve * listed also by IUCN; ${ }^{\text {w }}$ wet season; ${ }^{\mathrm{d}}$ dry season; ${ }^{\mathrm{r}}$ sighted in the river. Tc - pegadas; C - armadilha fotográfica; $\mathrm{F}$ - amostras fecais; I - entrevista; $\mathrm{S}$ - avistamento; $\mathrm{Tp}$ - armadilha; Vu - vulnerável; $\mathrm{Nt}$ - quase ameaçada; P - Área Privada; $\mathrm{R}$ - Reserva. * listado apenas pela IUCN; ${ }^{\text {w }}$ estação chuvosa; d estação seca; ${ }^{\mathrm{r}}$ avistado no rio. 


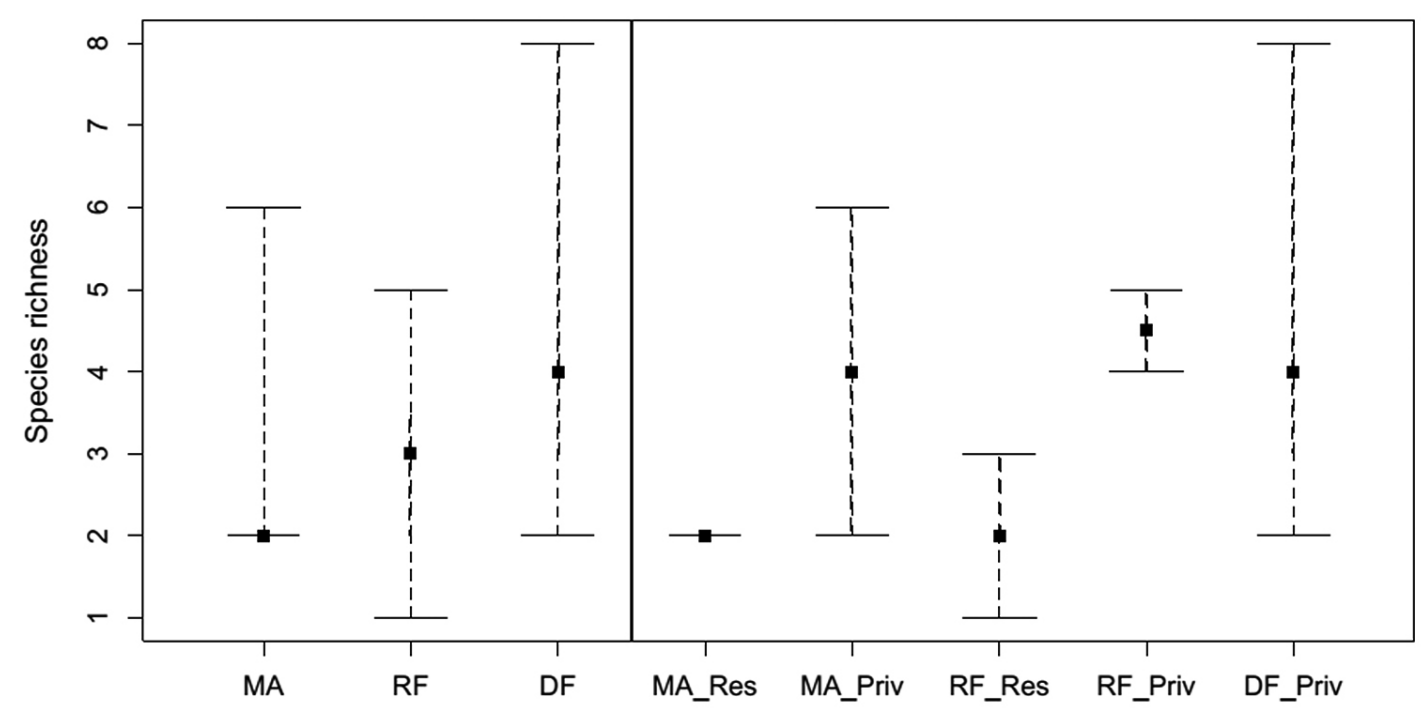

Figure 2. Species richness of large and midsized mammals in Cáceres, Mato Grosso, Brazil. Left side split by a dashed line shows data for private land and reserve together $\left(\mathrm{MA}=\right.$ marsh, $\mathrm{RF}=$ riparian forest, $\mathrm{DF}=$ dry forest). Right side shows data for each vegetation type separately by study areas ( $\_$Priv $=$ vegetation type at the private land, Res = vegetation type at the reserve). Dark square shows median species richness and whiskers show maximum and minimum richness recorded.

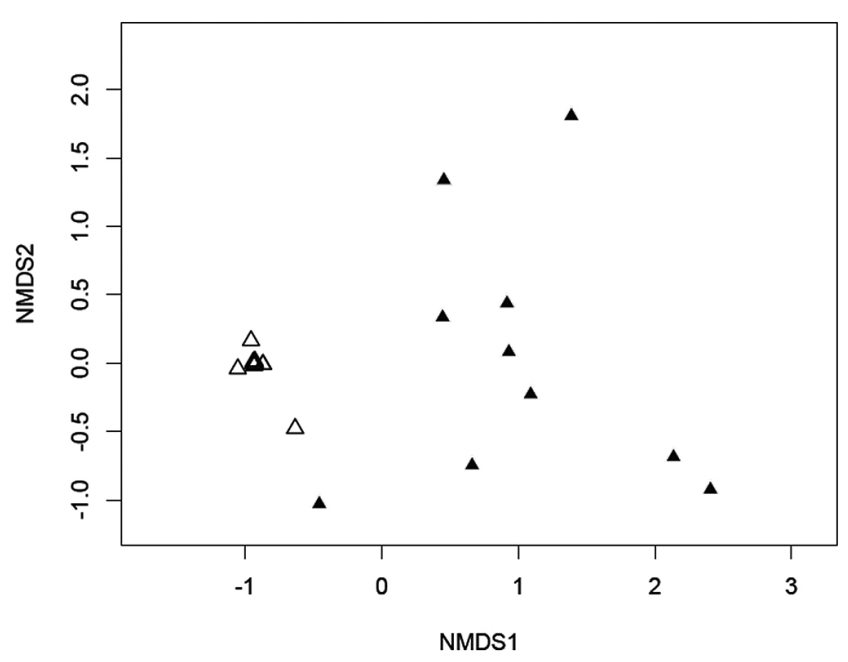

Figure 3. Non-metric multidimensional scaling (NMDS) plot based on a Jaccard similarity matrix, showing grouped based on species composition. Black triangles are the habitats sampled at Descalvados Farm - private land $(\mathrm{N}=10)$, and white triangles are the habitats sampled at Taiamã Ecological Station - reserve $(\mathrm{N}=11)$.

fact, the dynamics of animal movement for some terrestrial mammals are clearly affected by the availability of dry ground during the flood peaks (Alho et al. 2011).

Dry forests are typically at a higher elevation gradient, thus not affected by floods. This environment comprises a refuge for terrestrial species during the wet season. Good-swimmer mammals such as the jaguar, however, explore open and forested lands in riverine areas being able to cross rivers and forage over a large region (Crawshaw \& Quigley 1991, Mamede \& Alho 2006). Jaguars ranging patterns are generally more related to prey density (Crawshaw \& Quigley 1991) than to habitat availability (Ramalho \& Magnusson 2008). Herds of capybara are commonly seen at the river margins of the reserve, what might be influencing high densities of jaguars witnessed there (P.R. De Lázari, unpubl. data). Also, arboreal mammals, such as capuchin monkeys and howler monkeys, are less affected by hydrological cycles because they inhabit the canopy of forested habitats, finding food resources during floods (Alho \& Silva 2012).

Richness of large and midsized mammals simultaneously increased in the dry forests and decreased in the marshes according to the increase in river level and the volumetric rain increment, strongly suggesting that animals move from the marshes to the dry forests during flood peaks. This indicates that dry forests may be a refuge for these terrestrial mammals when marshes are flooded, and during the dry season animals leave dry forests to feed on nutritious grounds of marshes.

Moreover, marshes' richness is seemingly affected by the proximity to dry forests, as richness of marshes adjacent to dry forests is similar to the richness of dry forests; conversely, marshes isolated from dry forests (inside the reserve) have a lower richness than dry forests. In fact, three terrestrial species (two armadillos and a crab-eating fox) were only observed in those marshes associated to dry forests.

Species composition is distinct between the private land and the reserve, the latter has a less diverse community; thus, the yearlyflooded area in the reserve might be an ecological barrier to an array of large and midsized terrestrial mammals. Accordingly, interviewees report that after a massive flood in 1974 at least six terrestrial species disappeared from the reserve, also they state that the reserve did not use to be so widely flooded every year before it. However, the number of species recorded inside the reserve was considerably lower leaving $62 \%$ of the species present in the surveyed region recorded outside the reserve. This said, it is recommendable a different conservation approach for large and midsized mammals inhabiting protected and unprotected lands in the study areas, as protection of land not flooded (M. Santos-Filho pers. observ.).

The Pantanal of Cáceres harbours a rich community of large and midsized mammals similar to other regions in the Pantanal, however, a richer community inhabits unprotected lands outside Taiamã Ecological Station. In addition, this mammal fauna makes different use of space; a richer fauna inhabits dry forests, which serves as a refuge for species leaving marshes during flood peaks. Due to the differential use of space by large and midsized mammals we recommend conservation actions, such as protection of areas not 
affected by flooding, to preserve unprotected species inhabiting areas outside the reserve.

\section{Acknowlegments}

We thank Lenda Turism for allowing the research in Descalvados Farm. Many thanks to Daniel Kantek and Jair João Matia (ICMBio) for authorizing the research at Taiamã Ecological Station. We acknowledge FAPEMAT for financial support and to CAPES for Master's scholarship to PRL.

\section{References}

ALHO, C.J.R., LACHER, T.E., CAMPOS, Z.M.S. \& GONÇALVES, H.C. 1987. Mamíferos da Fazenda Nhumirim, sub-região de Nhecolândia, Pantanal do Mato Grosso do Sul: I - levantamento preliminar de espécies. Rev. Bras. Zool. 4(2):151-164. http://dx.doi.org/10.1590/S010181751987000200007

ALHO, C.J.R. 2008. Biodiversity of the Pantanal: response to seasonal flooding regime and to environmental degradation. Braz. J. Biol. 64(4): 957-996. http://dx.doi.org/10.1590/S1519-69842008000500005

ALHO, C.J.R., CAMARGO, G. \& FISCHER, E. 2011. Terrestrial and aquatic mammals of the Pantanal. Braz. J. Biol. 71(1): 297-310.

ALHO, C.J.R. \& SABINO, J. 2011. A conservation agenda for the Pantanal's biodiversity. Braz. J. Biol. 71(1):327-335.

ALHO, C.J.R. \& SILVA, J.S.V. 2012. Effects of Severe Floods and Droughts on Wildlife of the Pantanal Wetland (Brazil) - A Review. Animals. 2:591610. http://dx.doi.org/10.3390/ani2040591

AGÊNCIA NACIONAL DAS ÁGUAS - ANA. 2004. Programa de ações estratégicas para o gerenciamento integrado do Panatanal e da Bacia do Alto Paraguai. ANA/GEF/PNUMA/OEA, Brasília.

BRASIL. Ministério do Meio Ambiente - MMA. 2008. Livro vermelho da fauna brasileira ameaçada de extinção. Brasília. Biodiversidade, n.19.

CADAVID GARCIA, E.A. 1984. O clima no Pantanal Matogrossense. Embrapa-CPAP, Corumbá. Circular técnica, n.14.

CALHEIROS, D.F. \& FONSECA JÚNIOR, W.C. 1996. Perspectivas de estudos ecológicos sobre o Pantanal. Embrapa-CPAP, Corumbá. Documento, n.18.

CANALE, G.R., PERES, C.A., GUIDORIZZI, C.E., GATTO, C.A.F.R. \& KIERULFF, M.C.M. 2012. Pervasive Defaunation of Forest Remnants in a Tropical Biodiversity Hotspot. PLoS ONE. 7(8):e41671. http://dx.doi. org/10.1371/journal.pone.0041671

CRAWSHAW, P.G. \& QUIGLEY, H.B. 1991. Jaguar spacing, activity and habitat use in a seasonally flooded environment in Brazil. J. Zool. 223:357370. http://dx.doi.org/10.1111/j.1469-7998.1991.tb04770.x

DESBIEZ, A.L.J., BODMER, R.E. \& SANTOS, S.A. 2009. Wildlife habitat selection and sustainable resources management in a Neotropical wetland. Int. J. Biodiv. Conserv. 1(1):11-20.

DESBIEZ, A.L.J., BODMER, R.E. \& TOMAS, W.M. 2010. Mammalian Densities in a Neotropical Wetland Subject to Extreme Climatic Events. Biotropica. 42(3):372-378. http://dx.doi.org/10.1111/j.17447429.2009.00601.x

INSTITUTO BRASILEIRO DE GEOGRAFIAE ESTATÍSTICA-IBGE. 1992. Manual técnico da vegetação brasileira. Série Manuais técnicos em geociências. IBGE.
INTERNATIONAL UNION FOR CONSERVATION OF NATURE - IUCN. World Conservation International. 2012. IUCN Red List of Threatened Species. Version 2012.2. http://www.iucnredlist.org (último acesso em 27/10/2012).

MAMEDE, S.B. \& ALHO, C.J.R. 2006. Response of wild mammals to seasonal shrinking-and-expansion of habitats due to flooding regime of the Pantanal, Brazil. Baz. J. Biol. 66(4):991-998. http://dx.doi.org/10.1590/ S1519-69842006000600006

NUNES DA CUNHA, C. \& JUNK, W.J. 2009. Landscape units of the Pantanal: structure, function, and human use. In The Pantanal: Ecology, biodiversity and sustainable management of a large neotropical seasonal wetland. (W.J. Junk, C.J. Da Silva, C. Nunes da Cunha \& K.M. Wantzen, eds.). Pensoft Publishers, Sofia-Moscow.

NEVES, S.M.A.S. 2006. Condição climática de Cáceres/MT. In Simpósio Brasileiro de Climatologia Geográfica. DGEO-ICHS-CUR-UFMT, Rondonópolis.

PHILLIPS, M.L., CLARK, W.R., NUSSER, S.M., SOVADA, M.A. \& GREENWOOD, R.J. 2004. Analyis of predator movement in prairie landscapes with contrasting grassland composition. J. Mammal. 85(2):187195. http://dx.doi.org/10.1644/1545-1542(2004)085\%3C0187:AOPMIP $\% 3 \mathrm{E} 2.0 . \mathrm{CO} ; 2$

PINTO, M.N. 1986. Geomorfologia do Pantanal Matogrossense. In Anais do V Simpósio Brasileiro de Sensoriamento Remoto. Natal, v.1, p.78-85.

R DEVELOPMENT CORE TEAM. R: A language and environment for statistical computing. 2008. R Foundation for Statistical Computing, Vienna. http://www.R-project.org

RAMALHO, E.E. \& MAGNUSSON, W.E. 2008. Uso do habitat por onçapintada (Panthera onca) no entorno de lagos de várzea, Reserva de Desenvolvimento Sustentável Mamirauá, AM, Brasil. Uakari. 4(2):33-39.

RIBEIRO, J.F. \& WALTER, B.M.T. 1998. Fitofisionomias do Bioma Cerrado. In Cerrado: ambiente e flora. (S.M. Sano \& S.P. Almeida eds). Embrapa, Planaltina.

RODRIGUES, F.H.G., MEDRI, I.M., TOMAS, W.M. \& MOURÃO, G.M. 2002. Revisão do conhecimento sobre ocorrência e distribuição de mamíferos do pantanal. Embrapa Pantanal, Corumbá. Documento, n.38.

SANTOS, A.J. 2003. Estimativas de riqueza em espécies. In Métodos de estudos em biologia da conservação e manejo da vida silvestre. (L. Cullen Junior, R. Rudran \& C. Valadares-Padua, orgs.). Editora UFPR.

SCHALLER, G.B. 1983. Mammals and their biomass on a Brazilian ranch. Arq. Zool. 31(1):1-36.

SILVA, A. 2010. Geomorfologia do megaleque do rio Paraguai, quaternário, do Pantanal Mato-grossense, Centro-Oeste do Brasil. Tese de Doutorado, Universidade Estadual Paulista, Rio Claro.

SILVA, A., ASSINE, M.L., ZANI, H., SOUZA FILHO, E.E. \& ARAÚJO, B.C. 2007. Compartimentação geomorfológica do rio Paraguai na borda norte do Pantanal mato-grossense, região de Cáceres-MT. Rev. Bras. Cartogr. 59(01):73-81.

SILVA, M.P., MAURO, R., MOURÃO, G. \& COUTINHO, M. 2000. Distribuição e quantificação de classes de vegetação do Pantanal através de levantamento aéreo. Revta. Brasil. Bot. 23(2):143-152.

TROLLE, M. 2003. Mammals survey in the southeastern Pantanal, Brazil. Biodiv. Conserv. 12:823-826. http://dx.doi.org/10.1023/A:1022489426920

VOSS, R.S. \& EMMONS, L.H. 1996. Mammalian diversity in neotropical lowland rainforests: a preliminary assessment. Bull. Amer. Mus. Nat. Hist. 230:1-115.

WILSON, D.E. \& REEDER, D.A. 2005. Mammal species of the World: a taxonomic and geographic reference. 3rd ed. The Johns Hopkins University Press, v.1-2. 